\title{
カレンダーロールの研削についで
}

カレンダーロールの研削は, 胴長に比し眮径が小さ いため作業がもつかしく，高度な円筒度，真円度が要 求され，さら仕上り表面にはビビリゃ送りマーク等 のきずが残ることを非常隹ら。かつまたクラウニン

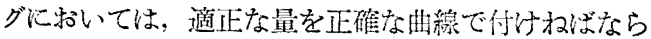
ず, 円简破削の中では最も困難なるのの一つとされて いる。

これらの要求を満足させ研削を行らには，次ぎの三 大要素が必要な条件となる。即ち

(1) 形削盤が㴊性度を持ち，かつ高精度なものでな 汸えばならないこと。

（2）砥石觉研削盤，被削材，研削手法等に適合した もの垐選択しなければならないこと。

(3) 研削手法においては, ロールの取付, レストの 潤滑, 研削諸元, 冷却水処理等の多くの要素を正 しく行わなければならないこと。

以下これらに関して述べると共に，当社で新設した "ランジスロール研削盤ルで得を結果を併せ述べる。

\section{I ロール研削盤について}

ロール研削盤は機械自身が洞性を有し，晢動面は， 酎磨耗性汇富及, 精度保持の可能なものであり, 特汇 碰石軸軸受の高精度なものでなければならないと言う ことは言を俟た烼ことである。次きたこれら重要な点 を，二三京げると，

(1) ベット

ベットは十分荷重に耐点，精度を保ちうる構造 のものでなければならない。站ってある意味から では，機械重量が重ければ重い程よいと言われて いる。

\section{(2) 主軸駆動装置}

主軸の駆動は，無段変速で自由に回転数を選び 得て, ギヤーマークの生じないVベルトやサイレ ントチェンにより駆動され，から円滑汇回転され らるだけの出力を持っていることが望ましい。

\section{(3) 砥 石台}

円滑な運転ができ，䃚石の回転数を無段変速で 自由に選びうるものでなければならない。特汇注 意して括かねばならないことは，䃨石駆動用モ一

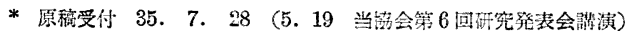

** 日立金属工業 $\mathrm{KK}$

\section{重松達 三**}

ターの振動が少なく, 防振装置が施されて, 取付 けられていなければならないことである。

\section{(4) 砥石軸軸受}

䂠石軸軸受汢研削盤の生命とも言われ，軸，軸 受ともに用性学持ち，適切な間隚を常に保ち5る 構造，村質のものでなければならないことが絶対 の条件である。

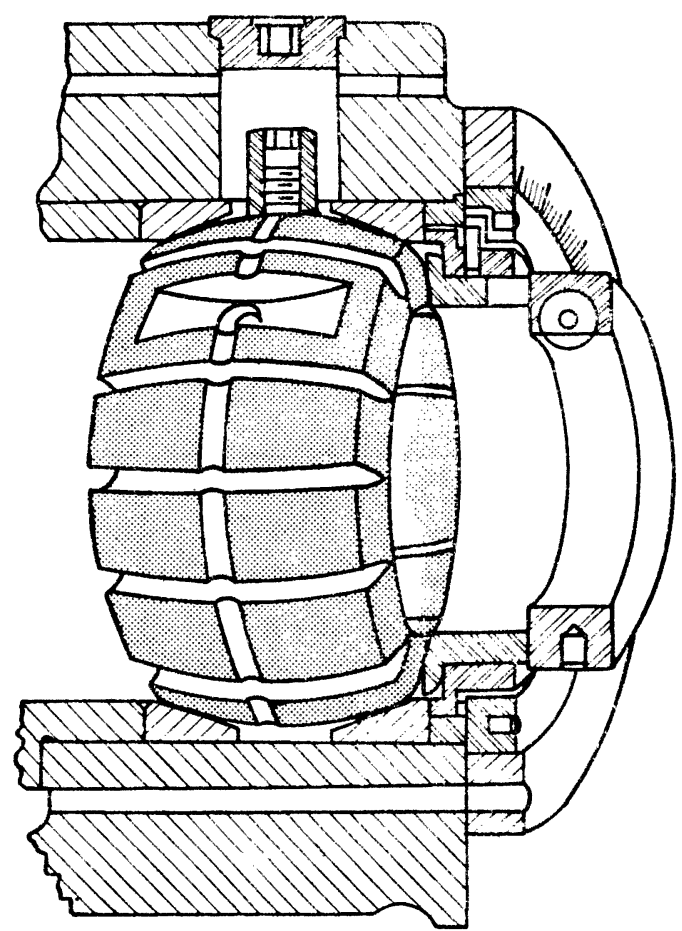

第 1 図 シンジスロール研削盤硅石軸受

ランジスロール研削盤は，第 1 図に示すよ5な， マイクロスフェアーと称垫られる軸受が佒用され て㧍り，過去 1 年半のフル運転で 1 度も調整を行 わず，初期の精度る十分保っている。

(5) 心押台，レスト

これは十分ロールを芝充るだけの容量と岡性と を持ったものでなければならない。

\section{(6) 冷却水濾過装置}

スクラッチを生ずる原因をなくすため，マグネ ットセパレーター，フィルターセパレーター等の 濾過装置を設置するか，或いは十分容量のまる沈 
潅槽を設けてやることが必要で あるが，最も望ましいことは，

この両者を併用することである。 以上，機械として特に留意せねねぱ ならない点でめるが，機械の精度を 維持し, 良い研削結果をうるために は, その機械基礎，据付にも細心の 注意を払って置かねばならない。

機械は機械自身が起こす振動と, 他の機械設備から播わる振動を防止 するためには，十分大きな基礎打ら を行うと共に, くい打ちを施行して, キルクゴム等の防振材を用い，基 礎打ちを施行することが理想的であ る。しかしながら, 工場の立地条件, 経費等の面から斯様な理想的な基礎 を施行することは殆んどできないの で，最悪の場合でも基礎の容量を十

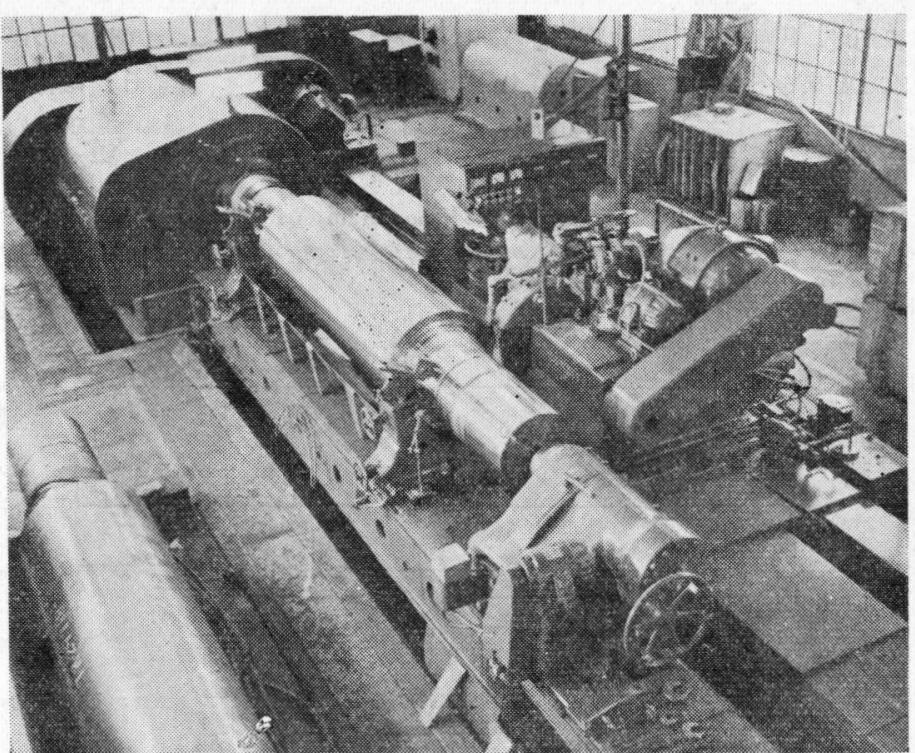

写 真 1 " ランジスロール研削盤の外観 " 分大きくし，基礎周辺に空間溝を設けることがいくぶ んでも振動防止に役立つことの一策である。

据付に当っては, ベットの芯出調整が容易に施行で きるようレベリングブロックを用い，据付場所の選定 には直射日光の当らないゴミの少ない場所で採光, 温 度変化等の点についても十分考虑することが必要でめ る。

参考までにランジスロール研削盤の外観を写真 1 に 示し，その仕様を記す。

"ランジスロール研削盤仕椂 "

称 呼………………...5 50 " $\times 288^{\prime \prime}$ 大型ロール研削盤

製作所……………... Landis Tool Company, Waynesbors, PA., U.S.A.

スイング $\vdots \cdots \cdots \cdots \cdots \cdots \cdots \cdots \cdots \cdots \cdots \cdots \cdots$

センター間距離…………7, 7,390 $\mathrm{m} / \mathrm{m}$ (最大)

研削最大重量…………65, $6000 \mathrm{~kg}$ (センター支持で)

クラウン最大研削量…... $12.7 \mathrm{~m} / \mathrm{m}$ (直径で)

主軸駆動用モーター….. DC $30 \mathrm{IP}$

砥石駆動用モーター….. DC 40 H

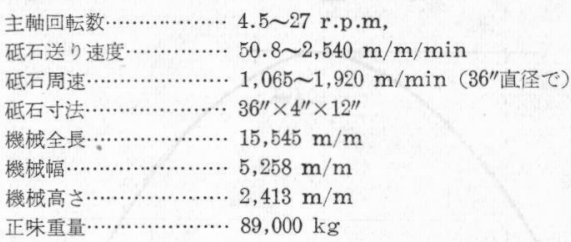

次ぎに本機の基礎は，当工場が埋立地に在り，かつ 地下水の水位が高いため, 第 2 図に示すようにくい打 ちは施行せず，基礎底面を大きくして地耐力を大きく とり, 基礎重量を約 450 とし, 基礎への浸水, なら びに湿気防止のためと, いくぶんです振動を吸収させ る目的で，基礎の側面と下面とにアスファルトを打ち， さらに基礎の周囲には空間溝を設けた。機械据付のた めには，基礎上面に機峨加工を施した I ビームを埋め， この上にレベリンブグロックを置くようにして，機械 精度の保持に考慮を払った。

これにより, 機械据付, 調整後の精度検査に拝ける

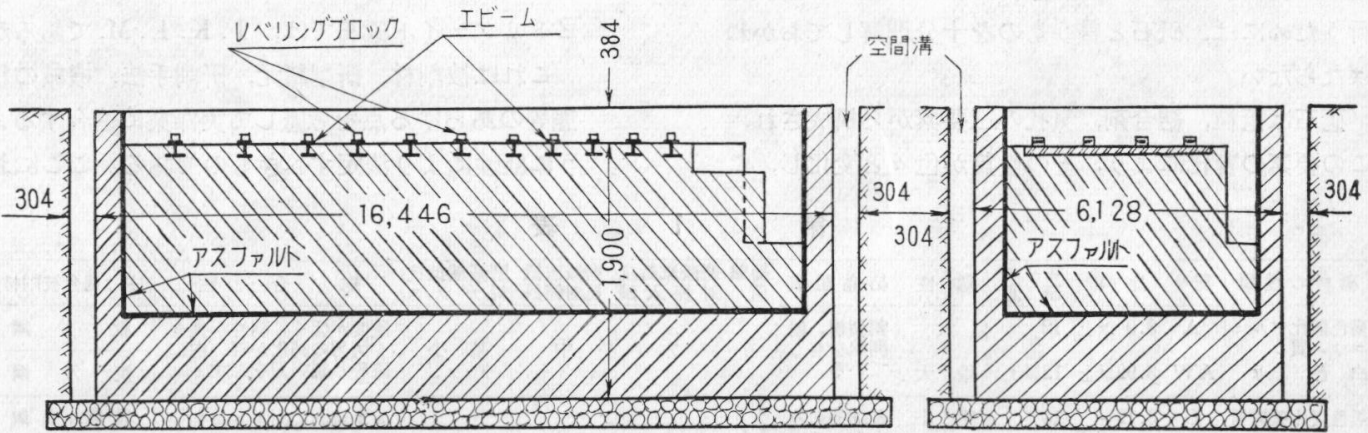

第 2 図 ランジスロール研削盤基礎略図 
真円度, 円筒度の測定結果, ならびにクラウン曲線の 測定結果をとれぞれ第 3 図，第 4 図に示す。円筒度と クラウン曲線は, $1 / 1000 \mathrm{~m} / \mathrm{m}$ 単位のダイヤルインジ ケータの付いたロールキャリパスで，真円度は簡単に 測定ができないので，振れと併せて $1 / 1000 \mathrm{~m} / \mathrm{m}$ 単位 のダイヤルインジケータを用いて测定を行った結果で める。

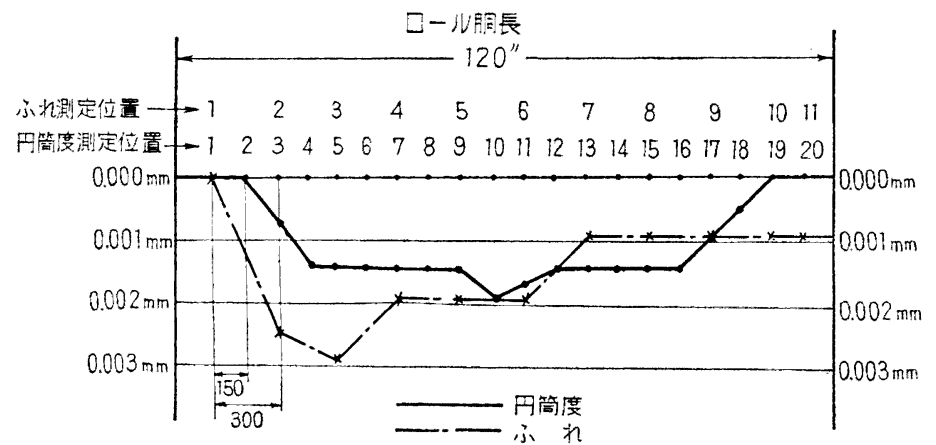

第 3 図 円简度および振れ測定結果

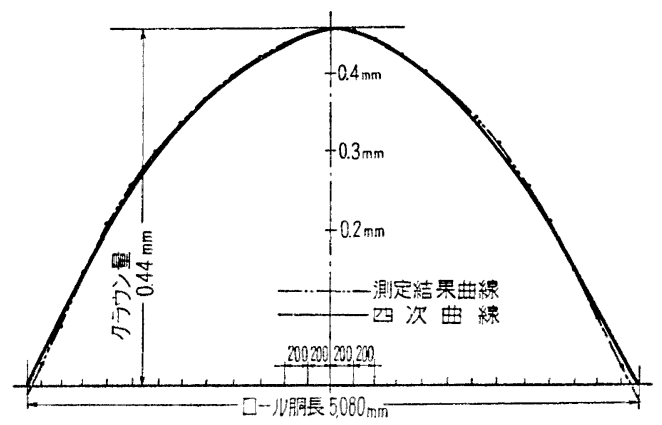

第 4 図 クラウン剆定結果と基準線

\section{II 砥石の選択について}

研削盤がいかに立派であっても，研削に当って硑石 が被削材，研削手法に適合したものでなければ満足な 研削結果をうることは困難である。研削作策における 䃌石の持つ役割は非常に大きく，正しい砥石の選択を 行うためには，䂠石と言うるのを十分理解しておかね ばならない。

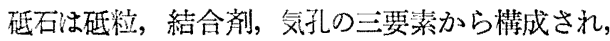
この要素の変化により，その性質が色々と变化し，こ
れを五つの要素として表示している。即ち，

\section{(1) 砥材の種類}

砥石の切刃を構成する人造砥材には，第 1 表に 示す 4 種類があり，各々その物理的，化学的組成 を異にしている結果，これにより砥村の選定を行 わねばならない。

一般に鋳鉄系ロールの研削には，C材碈と GC 砥材が用いられるが， 近時カレンダーロールに広く使用 されている合金チルドロールには GC 䃌材が適している。

\section{(2) 粒 度}

粒度とは诋粕の大きさを表わ するので，㼋削内容，仕上り表 面の要求度により巽択すべきも のである。

粗粒のものは重研消や粗仕上 に，細粠のものは僌研削や上仕 上に用いられ，微糔のものは鏡面仕上に用いられ ている。

一般に用いられている粒度を示すと，

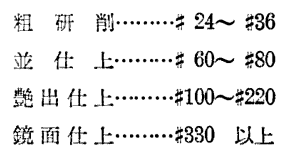

当虬では，未だ日本で製造されていない大型の 微粒砥石を，米国のカーボランダム社より輸入し て，鏡面仕上げを行っているので，写頡 2 , 写真 3 に国産の げた研削面を比較して示しておく。

\section{(3) 結 合 度}

結合度は硬度とも呼ばれるもので，硅粒を保持 する結合剤の強さで心る。現在ビトリファイド䃌 石についてのみJ I Sが制定されている。

一般にロール磻に使用されている結合度は, ビトリフォイド䂠石では，J．K．L．M.であるが， これは被削材, 研削諸元, 研削手法, 機㭜の状 態等のあらゆる点を考慮して実作業に適合するよ うに経験により決定すべきものである。ここに打

\section{第 1 表}

\begin{tabular}{|c|c|c|c|c|c|c|c|c|c|c|c|c|c|}
\hline 䂠材の種類 & 婄号 & & 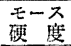 & & 結晶組成 & 奮撃 & 磨溜隇抵抗 & 黁隇娍抵 & 磨減娍抵抗 & 総 & 合 & 性 & 主な適合被削材 \\
\hline 褐色酸华アルミ & $\mathbf{A}$ & 3.9 以上 & 12 & 大 & 割裂線, 璧 & 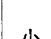 & + & 中 & & \multirow{2}{*}{\multicolumn{3}{|c|}{ 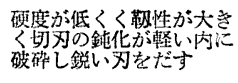 }} & 鋼 \\
\hline 白色 " & $\mathrm{AW}$ & 3.92 以上 & 12以上 & 稍 大 & & 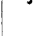 & 人 & & & & & & 入 \\
\hline 黑色岑化碃素質 & C & $3.12 \sim$ & 13 & 稍 小 & 壁閉線のみ & t & 中 & t. & t. & \multirow{2}{*}{\multicolumn{3}{|c|}{ 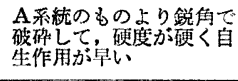 }} & 鋳鋼, 黄 銅 \\
\hline 色 & G C & & 13以上 & 小 & & 人 & $T$ & 人 & 人 & & & & 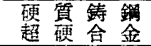 \\
\hline
\end{tabular}




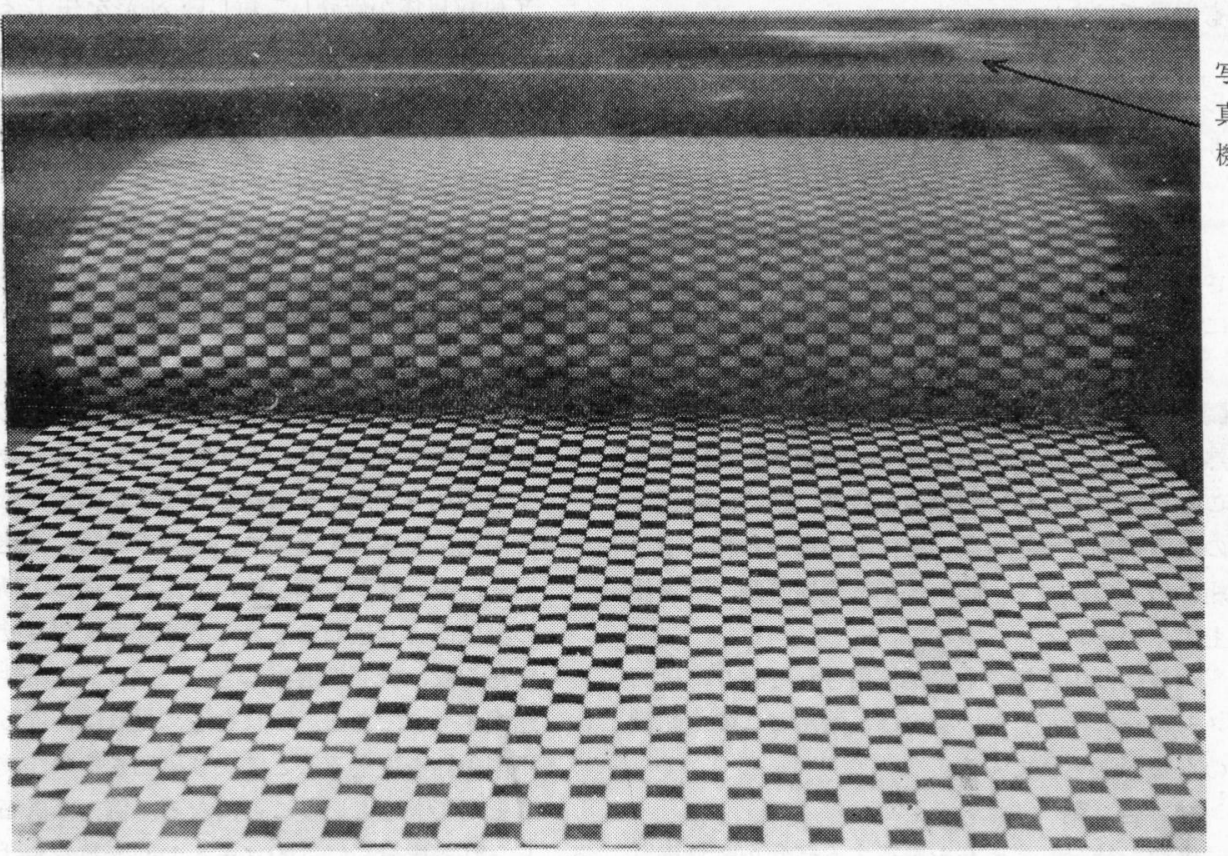

写真 2 国産“GC-100-K-Vit”による嚖出仕上面

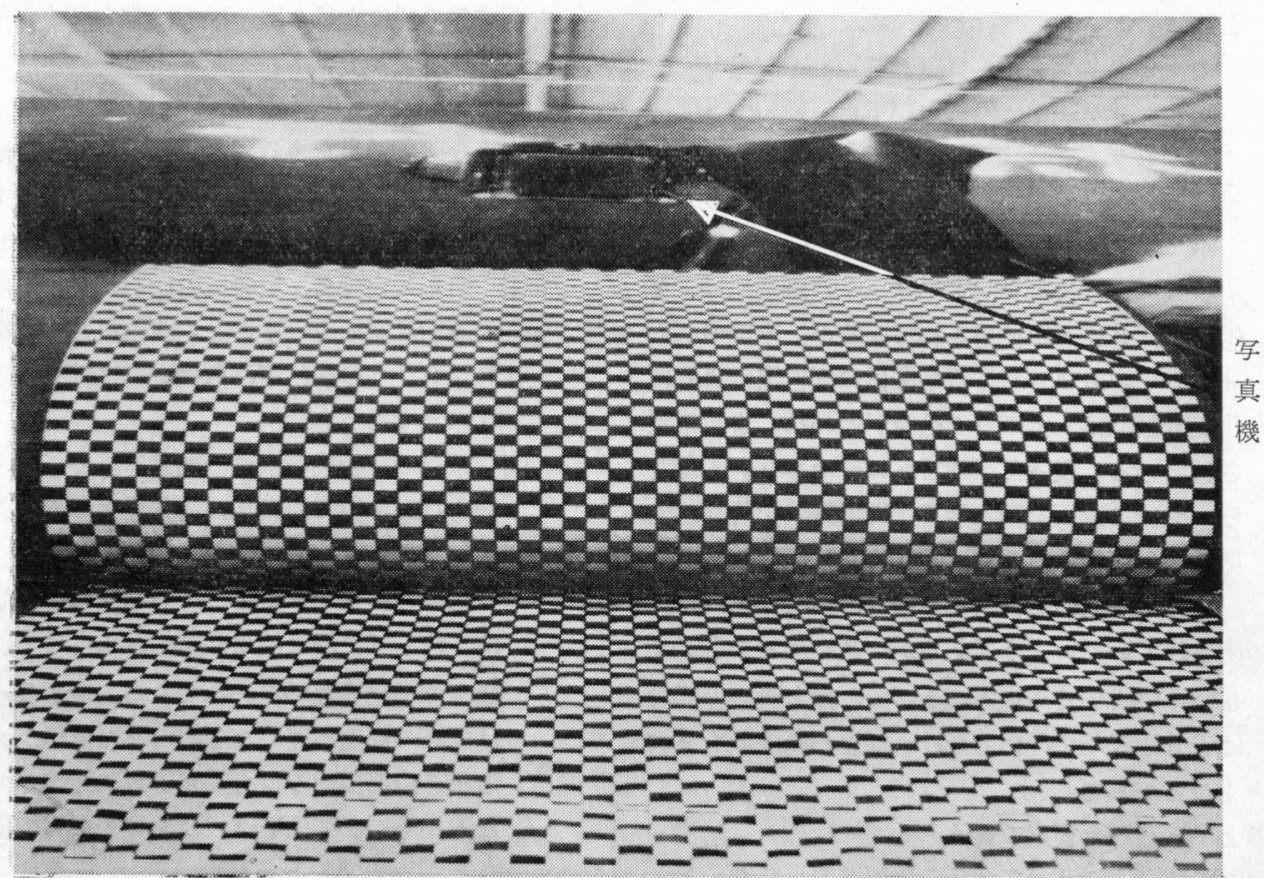

写 真 3 カーボランダム社 “微粒砥石 (A-HF-M-BY)”による鏡面仕上の面

いて最も注意して置かねばならないことは，結合 度の段階は蕨密な度量を示するのではなく，ある 二つの限度間の限界を示するので，その限界内に むるものはすべて同一記号で販売されていると言
らことである。即ち, 同一記号の同一メーカーの ものでも, 結合度の差異をはっきり感ずることも あり，また同一記号でもメーカーが異なれば，殆 んどといってよい程結合度の差異があると言って 
も過言ではない。

従って結合度の選定化当っては，常俔場，な らびに砥石メーカーと密接な連絡をとりながら行 うことが重要なことである。

\section{(4) 組 織}

組織とは研削作業江打河㴔排出機棈をつか さどる砥石の気孔の大小, 即方砥石の単位容䖽中 にある砥粒率であり，気孔率ではない。

組織の変化が研削作業におよ持す影響は大きく， 調整された組織を有するものは，切味が優れ，発 熱が少なく，仕上面が良好で，高能率を発揮する ことができる。粗い組織のものは, 軟く, 展延性 の岕る被削村や重斫削, 粗仕上汇用いられ, 密な 組織のものは硬く, 脆い被削材や軽研削, 精密仕 上泪いられる。

一般には中組織の羊のが使用されて和り, 研石 メーカー化指定しない場合は, 殆んどこの中組織 のものが送られてくる。

\section{(5) 結 合 剤}

䃨椟を結合して砥石を製造する結合剂に無機質 と有機質のものとがあり，次ぎにその種類を示す 々,

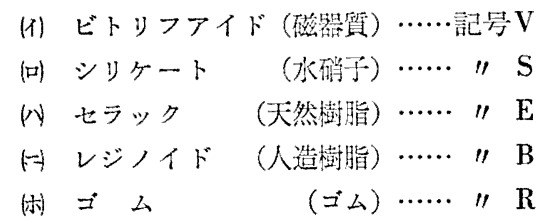

我国に拉けるカレンダーロールの研削には，V 硅石か，B砥石が使用されているが，米国の砥石 メーカーのカタログや研削関係の報告書によれば， 仕上研削には，セラック砥石が使われ，また推奨 されている。良って当社でもカーボランダム社か らセラック䃈石を翰入して, 研削試娩を行うべく 準犕を進めている。

また，B砥石を使用する場合，確実な原因は究 明されていないようであるが，スクラッチが必ず そいってよいくらい入いるので，仕上研削の場合

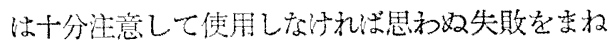
くことが心る。

以上が䃚石の五要素である。

次ざに結合度に関して砥石の使用上の点について今 少し述べると,

研削扎いては，砥石の自生作用と称せられる砥石 特有の切削過程を生じるが，これは研削過程に叔る

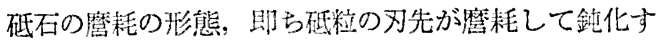
る゙すりへり麿耗 ゙と, 䂠稙の割裂線, 壁開線によっ

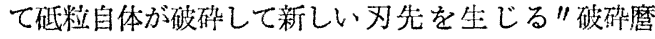
耗 几と，研削抵抗が碰粒を保持する結合剤の結合度よ り大きくて，砥䊀が脱落して新らしい碰粒が現われる "脱落麿耗 “との三つの形態があるが，破䂥磨耗と脱 落䗪耗とが䃌石の自生作用と称せられるものになる。

ここに䗆いて硅石の使用に当っては, 砥粒の早く脱 落するものが軟らかく感じ，脱落の遅いものが硬く感 じられるので，研削諸元を落えることにより䂠粒に衝 く荷重を変化させ, ある程度, 結合度の感じを変える ことが呵能である。研削では, 砥石と工作物とが共に 回転寺るので，お互いの回転数を変えることにより，

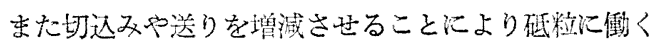
研削抵抗が変化するため, 碈粹の脱落に迤速を生じて, 硬く, 或いは軟く感じるのである。従って斯椂涶々 の現象により䃍石の性質は或る程度变化させうるもの である故，碈石の選択に当っては，研削条件に応じて 選択すべきである。これる逆汇見れば，或る範理では 研削条件を変点ることにより䂠不をその作業に合せる ことができるということになる。例兄ば碈石が硬く感 じられる場合には，(1)上ールの回転数をあげる，(吅䃨 不の送りをあげる，以切远及を增す，目砥石の回転数 を落す等の操作を行党ば，砫石は軟らかく作用する。

\section{III 研削手法について}

满足な研㴥結果を得るためには, 正しい研消手法を 用いなければならないので，これらについて主な点を あげると，

（1）新らしい砥石, 取替舞の䂠石は必ず研削作業に 入る前空転を行うこと。また䃨石の運搬, 保管, フランジへの縍付等, 取报いには細心の注意を行 うべきである。

（2）䂠石の空転後の機械の始動に当っても，必ず空 転を行い，機械の異状の有無を確めるべきである。

(3) 䃚石のバランス

䃨石のバランスがとれておらず研削した場合 は，決して良好な結果は得られるものではなく， 仕上面汇縞模様が現われてくる。砥石のバランス は祗石の周速が速くなる程，また直径が大きくな る程，砸石表面の遠心力が旮れに比例して大きく なるから，必当䂠石はバランスをとって使用する ことが大切である。

䃨石は集造業者により殆んどバランスがとられ ているので，䃚石用フランジ (wheel mount) に 錘のついたものを用い，この鉭の移動によりバラ ンスをとれば大体に执て十分である。

(4) ドライブドッグ（けれ）は工作物に固くクラン 
プして，必ず片けりをするようなるのを使用して はならない。

(5) ロールの駆動㲹当っては, 特にレスト作業にお いては，片けりをすることを絶対さけねね゙正しい 真円度を得ることはできない。

(6) レストの使用法

ロール研削では，ロールメーカーの一部の作業 を除いては殆えどンストを用いて作業が行なわれ るが，レストは 2 カ所用いるのがビビりの出方が 少ないとされている。またロールの括どりを防止 するために必ず押党（hold down clamp）を使用 すべきである。

次ぎにレスト作業において最す注意すべき点は， ロールネック化対する潤滑であり，適切な潤滑が 行なわれない場合は，ロールネックが不均一な熱 膨脹を行ない，歪を生じて真円に研削ができず， またそれぞれのレストの潤滑状沉が異なれば，そ の熱膨脤の差によりテーパーに研削される原因に もなる。従って油で浸した毛布やフェールトをレ スト上のロールの表面汇密着させて, これ沉常に 同一量の油を均一汇滴下させてやることる，上記 の欠陷を防ぐ一つの方法でも㐫る。

さらに研削中の泠却水の乘沫がレストに飛込む ことにも十分注意してやら齐ば上記と同じょうな 欠陷を生ずる結果となる。

（7）冷却水，お゙び処理

冷却水はロールの泠却効果にの及用いるもので なく，砥石面やロール面を清浄するために用いる ものであるから，洗湅性を有するものでなければ ならない。また冷却水に唀明なものを使用する ことも重要なことである。これは要求仕上面を得 るために，作業者は常沉研削中もロール表面を見

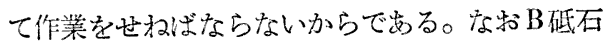
を使用する場合，アルカリ度の高い渝却水を用い

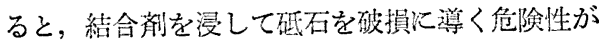
めるので，アルカリ度の高いものは使用をさける べきである。

次ぎに冷却水は循環させて使用するため完全に 濾過を行い，脱落した砥粒や切屑を除去してやら ないと，スクラッチの原因をつくることになる。 従ってセパレーターや沈敗槽を用いて十分異物を 除去すべきである。

(7) 䃨石のドレッシング

砥石を正しくドレッシングすることは，ロール を要求された仕上面汇研削するためには重要な要 素でめる。ドレッシングには，砋石を真门に形直
しすることと，砥石の目詰りを取除くための目的 がある。ドレッシング作業汇は，ダイヤモンドド レッサーが一般使われ，ダイヤモンドの冈先は 鋭いことが必要である。

作業に当っては, 送り速度 $0.15 \mathrm{~m} / \mathrm{min}$ で, 送 り每汇約 $1 / 100 \mathrm{~m} / \mathrm{m}$ の切込及を与え, 最終ドレッ シングの送り方向は, 最初のドレッシングの方向

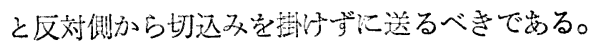
最終ドレッシングの目的は, 前のドレッシングで 砥石が鋭く高くなった所が工作物倿触すると， 直ち汇破磪して fish tail と称せられる模椂がで きるのを防止するためのるのである。荒いドレッ シングが行なわれると，砥粒が浮上り，スクラッ チの原因となるので，ドンッシング後，砥石面を ブラシでこするか，冷却水を十分か子て脱落すべ き碰粒を洗い落してやるとよい。

ダイヤモンドマークが研削面に現われるのは， 非常汇処理に困るものであるが，これはドレッシ ングの際の切込久が大き過ぎたり，送りが速過ぎ たりした結果である。特㑎粒砥石に尔いては， ぞんな方法を用いても，ドレッシング後，そのま ま研削すれば仕上面化きずが入ると言われている ので，この場合はロール端部で泠却水をかけず， また送りもかけずに軽るく砥石をロール沉当てて やると，きずは完全に入らなくなる。

ダイヤモンドの研削角度は, 第 5 図の如く水平 に $30^{\circ}$, 上下に $3^{\circ} \sim 15^{\circ}$ 程度傾けてやるのが効果 的である。

次ぎにドレッシングを行う場所であるが，これ

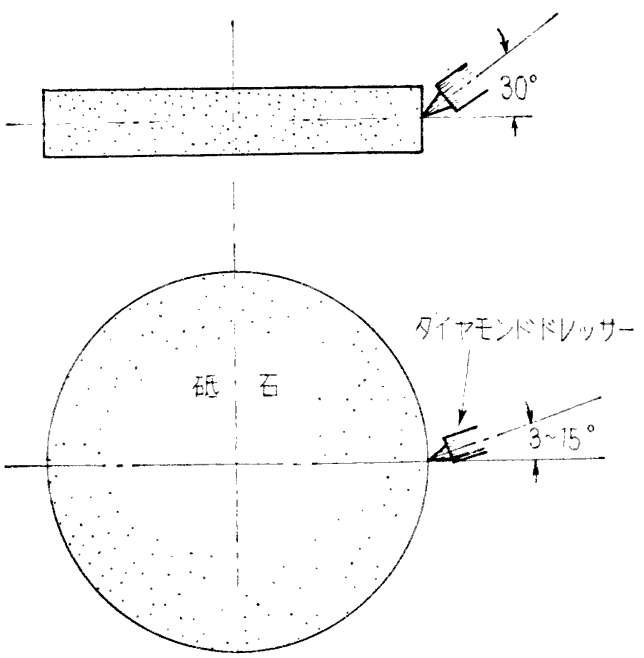

第 5 図 ダイヤモンドドレッサーの触 


重松達等

は一般に，ダイヤモンドドレッ サーが心押台に装置されている ので, 研削する場所とは離れて いることになり，どんな正確な ベットでも，離れた二点間の間 では若下の振れがあるため，研 削面と完全に平行な砥不面を得 ることが困難である。彷って， 特に上仕上げを行う場合には， 研削個所でドレッシングできる ような手段を誰ずることが，よりよい結果と生む ことになる。

(8) 影削の方法

カレンダロールの再研削に出いて，一般には早 く仕上げるために重砄削を行うことはできるだけ さけ，軽研削学行なう方がより效果的である。こ れは砥石の磨耗が少ないため, 早く円简度が总ら れ，また重酳によるビビリを除くのに時間がか かるためである。

研削の熟練者は，その研削音で切込及深さを想 定することができると言われているが，砥石駆動 用モーターの電流計の読及を一行程中, 常に一定 に保ち，切込又を一定にする操作を行うことが大 切である。

工作物の周速は，カタログや報告畫によると， 直径 $500 \mathrm{~m} / \mathrm{m}$ までは $25 \mathrm{~m} / \mathrm{min}$ 程度, $500 \mathrm{~m} / \mathrm{m}$ 以 上のものでは $35 \mathrm{~m} / \mathrm{min}$ 櫫度とされているが，力 レンダーロールは胴径と哃長の比が大きいため, 周速を增すと曲りや振動を起し，ビビリが生ずる 原因となるので，これを防此するには，周速を減 じて作策することが㞗々である。かつまた，研削 中に速度変换をしてやることも，ビビリ防止の一 策である。

粗牒から仕上研削に到る過程においての研削 手法は，

(1) 砥石周速……徐々に減ずること。

(D) 工作物周速……徐々に增やすこと。

仪 砥石切込……送り目が消光るまで

逐次減少させ，電流計の読みが無負荷の時 より $3 \sim 5 \mathrm{Amp}$ 多くなる程度で最終仕上を 行うこと。

甘送りの折返……砥石送りのロール胴端に拉 ける折返の場合，砥石のオーバーハングは， 逐次減少させ，最終仕上には胴端から $3 \sim 6$ $\mathrm{m} / \mathrm{m}$ 程度以上でないようにしてやることが 大切である。これは，第6戍に示すように，
中央部の通切な目詰り 部がロール端面で破䂶 “正しい送り中央部の適切な目詰り を維持できる

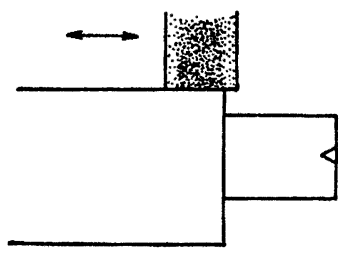

第 6 図

㴥めらかになった砥石面が，閅端の縁で破确 されることを防いで，仕上りを早く，きれい にするためである。

以上, カレンダーロールの研削について, 研削盤, 砋石の選択, 研削手法で留意しなくてはならない点を 述べたが，最後に研削中に起る不良事項と，その処置 について述べると，

(1) ビ ビ リ

これは，広幅に正しい週期か，或いは細く不規 則な週期で現われたり，タタキ模様の形状で現わ れることがある。ビビリの原因は，砥石のアンバ ランス, 低石軸軸受のガタ, 硬過ぎる砥石, 硑石 の目詰り等がある。その他, 砥石駆動用モーター の振動やプーリーのアンバランス，ロール回転の 不規則，機峨の振動等によって生ずることもある から，これらを確認することが解決策である。

(2) ラセン模様

ロール面にラセン状に入る模様である。これは， ヘッドストックと心押台の芯が喰違っていたり砥 石面がテーパーにドレッシングされた場合に生ず る。また砥石の縁が荒れている場合にも生ずる。 推って，心押台の芯を修正するか，ドレッシング の方法や，取付角度等を検討与ればよい。

(3) 衫讨付き

これはロール面の変色により簡単に判別される。

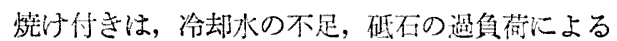
むのであるから，研削液を十分注ぎ，切込2量を 減じ，或いは砥石が便すぎるので，軟い砥石に取 替えてやることで防止できる。特にロールの回転 が止まっている時，砥石がロールに当らないよう に注意すべきである。

(4) スクラッチ

これについては，前に度々述べたが，冷却水の 濾過を十分行ない，またドレッシングを正しく行 うことによって防止できる。さらに硬い，細い砥 粒を低用することによりスクラッチは，さけえら 
れる。

上記の上了に研削中の不良事項は, 研削盤, 砥石, 被削材，研削手法のいずれがその原因がひそんでい るものである。原因が判らないと考兄られる場合にる， 原因がーつのみでなく，三つ，三つと重なっているこ
とが多くめるので，あらゆる面から詳細に検討すれば， 原因も究明されるが，乙かしながら長い期日を要する 場合や，多額の金を要する場合もあるので，根よく原 因は追究しなければ改善は困難である。

\section{ブナ材の腐朽対策}

(762 頁より)

はなく広葉樹の大半を保有している国沈いても充分 考えてくれなければならないことで，これが即ら木材 利用合理化の重要な出発点であると思考する次第であ る。

最後に種々御教示を賜わりました工場山林部並びに 管理部の諸氏に深謝致します。

\section{引用文 献}

1) 伊藤: 木材空朽

2）逸見，赤井：木材窻朽菌学

3) J. G. Sheridan: PPMC 59 No. C 228 (1958)

4) 芝本: 木材工羣 12 No. 127, No. 128 (1957)

5）佐々木：社内報（末公表）

6) 浅野, 藤并 : 木材工業 72 No. 3, 118 (1953)

7）山下：社内報（未公表）

8) TAPPI : Microbiology of Pulp and Paper 1955

9) H. Meier: Holz Roh-u Werkstoff $9323(1955)$

10）今関: 木材工業 10 No. $5,209 \sim(1955)$

11）佐々ホ：グリーン・エージ 7 No. 11, 23〜 (1957)

12）塚本：社内報（未公表）

13）内藤：ダリーン・エージ 9 No. 10, 10〜 (1959)

14）清: 未発表

\section{合成樹脂ベルト}

(765 頁より)

なり，安全運転と安価を得ることが出来ましょう。

\section{(4) Long life}

繰り返し述べる如く未だ 1 力年余の使用経験しかな いので今後どの位使えるのか全く見当がつきません。 そもとも long life と言うこと自体すら周囲の状沉，
ベルトの速度, 負荷等多数の条件の他に主観によって 異なり容易に決めかねるので，この件に関しては全く 各位の御判断に沶任かせすることと致します。

\section{(8) True running}

各パート間のドローが安定して運転が正確であるか ぞうかは, 過去の測定値もないしこのベルトになって からの数値むないので, このような意味での True running は何んとも申し上げられません。然しベルト の伸びによるスリップ, 接手の不良及び切詰め等の事 故が少ないから運転が確実であると言う意味ならゴム ベルトに比較して何倍も確実であります。それは今ま で運転中にこのベルトのために機栈を停止したことが 1 回も無いことで明らかでしょう。今後更に長い使用 によって正碓な運転 安定したドローー紙切れの減少 を管理図から確認することが出来ればと思って拈りま す。

\section{5. 結 び}

以上到って雑駁な報告でさして御参考にならないか も知れませんが，ゴムベルトを使って苦心しておられ る方々に少しでも役立てば幸であります。幾分自画自 賛の傾向も山りますが，私はこのベルトに対して”期 待はずれの点”が無かったことだけは確かであります。 外国では $1,500 \mathrm{ft} / \mathrm{min}$ まではこのベルトを使って充 分であると報告されているのでセクショナルドライブ, ディフェレンシアルギヤー或いはバリピッチ等多額の 改造費を出さずに目的を果すことが出来ればこれ越 したことは無いので敢えて拙文を揭げました。 な蛙詳しくは下記を御覧願い度い。

Paper Trade Journal May 6, 1957

" " " September 28, 1959

Pulp \& Paper Magazine of Canada, March 1959 